\title{
Cigarette Smoking Increases Pregnancy-associated Plasma Protein-A in Men
}

\author{
A Coskun ${ }^{1}$, I Bulut ${ }^{2}, \mathrm{M} \mathrm{Serteser}^{1}$, A Eren ${ }^{2}$, ZF Ozseker ${ }^{2}$, Ç Çuhadaroğlu³ ${ }^{3}$ FB Aksungar ${ }^{1}$, \\ A Özpınar ${ }^{1}$, Ö Can ${ }^{1}$, HI Yakar ${ }^{2}$, İ Ünsal ${ }^{1}$
}

\begin{abstract}
Objective: Elevation of pregnancy-associated plasma protein-A (PAPP-A), a pro-atherosclerotic molecule, has been shown to be an independent risk factor for acute coronary syndrome. Smoking is also an important risk factor for acute coronary syndrome (ACS). However, the molecular mechanism of this relationship is not clear. In the present study, we aimed to determine the association between smoking and serum PAPP-A levels in men and non-pregnant women.

Method: The study population consisted of 112 smokers and 58 age-matched non-smoking healthy subjects as a control group. Blood samples were drawn from the antecubital vein of all subjects and serum PAPP-A levels were measured using an ELISA kit (ultrasensitive ELISA).

Results: The serum PAPP-A level was significantly high in male smokers (smokers: $9.11 \mathrm{ng} / \mathrm{mL}(3.10$ $\mathrm{ng} / \mathrm{mL}, 18.55 \mathrm{ng} / \mathrm{mL})$ ); controls: $7.44 \mathrm{ng} / \mathrm{mL}(<0.023 \mathrm{ng} / \mathrm{mL}, 16.54 \mathrm{ng} / \mathrm{mL}) ; \mathrm{p}<0.05))$ but not in female smokers (smokers: $4.49 \mathrm{ng} / \mathrm{mL}(<0.023 \mathrm{ng} / \mathrm{mL}, 11.92 \mathrm{ng} / \mathrm{mL})$; controls: $5.95 \mathrm{ng} / \mathrm{mL}(<0.023 \mathrm{ng} / \mathrm{mL}$, $15.61 \mathrm{ng} / \mathrm{mL}) ; \mathrm{p}>0.05)$ ). In male smokers, the correlations between serum PAPP-A levels and age, body mass index (BMI), duration of smoking (years), and number of cigarettes smoked per day were not statistically significant $(\mathrm{p}>0.05)$.

Conclusion: Serum PAPP-A levels are higher in male smokers, and this may indicate a higher risk for ACS among men.
\end{abstract}

Keywords: Acute coronary syndrome, lung cancer, pregnancy-associated plasma protein-A, smoking

\section{Fumar Cigarrillos Representa para los Hombres un Aumento de la Proteína Plasmática A asociada al Embarazo}

\author{
A Coskun ${ }^{1}$, I Bulut ${ }^{2}$, M Serteser ${ }^{1}$, A Eren ${ }^{2}$, ZF Ozseker ${ }^{2}$, Ç Çuhadaroğlu ${ }^{3}$, FB Aksungar ${ }^{1}$, \\ A Özpınar ${ }^{1}$, Ö Can ${ }^{1}$, Hİ Yakar ${ }^{2}$, İ Ünsal ${ }^{1}$
}

\begin{abstract}
RESUMEN
Objetivo: Se ha demostrado que la elevación de la proteína plasmática A asociada al embarazo (PAPPA), una molécula pro-aterosclerótica, constituye un factor de riesgo independiente para el síndrome coronario agudo. El hábito de fumar es también un importante factor de riesgo para el síndrome coronario agudo (SCA). Sin embargo, el mecanismo molecular de esta relación no está claro. En el presente estudio, apuntamos a determinar la asociación entre el hábito de fumar y los niveles séricos de PAPP-A en los hombres y en las mujeres no embarazadas.

Método: La población del estudio estuvo formada por 112 fumadores y 58 sujetos saludables no fumadores pareados por edad como grupo de control. Se tomaron muestras de sangre de la vena antecubital de todos los sujetos, y los niveles de PAPP-A en suero fueron medidos usando un kit de ELISA (ELISA ultrasensible).

Resultados: El nivel de PAPP-A en suero fue significativamente alto en los hombres fumadores (fumadores: $9.11 \mathrm{ng} / \mathrm{mL}(\mathrm{ng} / \mathrm{mL} 3.10,18.55 \mathrm{ng} / \mathrm{mL}))$ controles: $7.44 \mathrm{ng} / \mathrm{mL}(\mathrm{ng} / \mathrm{mL}<0.023,16.54 \mathrm{ng} / \mathrm{mL}) ; \mathrm{p}$ $<0.05)$ ) pero no en las fumadoras (fumadores: $4.49 \mathrm{ng} / \mathrm{mL}(\mathrm{ng} / \mathrm{mL}<0.023,11.92 \mathrm{ng} / \mathrm{mL})$; controles: 5.95 $n g / m L(<0.023 n g / m L, n g / m L ~ 15.61) ; \mathrm{p}>0.05)$ ). En fumadores masculinos, las correlaciones entre niveles de PAPP-A y edad, indice de masa corporal (IMC), duración del hábito de fumar (años), y el nú-
\end{abstract}

From: ${ }^{1}$ Department of Medical Biochemistry, School of Medicine, Acibadem University, ${ }^{2}$ Sureyyapasa Chest Disease and Chest Surgery Training and Research Hospital and ${ }^{3}$ Department of Chest Disease, School of Medicine, Acibadem University, Istanbul, Turkey.
Correspondence: Dr A Coskun, Department of Medical Biochemistry, School of Medicine, Acibadem University, Atasehir, Istanbul, Turkey. Email: Coskun2002@gmail.com 
mero de cigarrillos fumados por día, no fueron estadísticamente significativos ( $\mathrm{p}>0.05$ ).

Conclusión: Los niveles de PAPP-A son más altos en los fumadores masculinos, y esto puede indicar un riesgo más alto de SCA entre los hombres.

Palabras claves: Síndrome coronario agudo, cáncer pulmonar, proteína plasmática A asociada al embarazo (PAPP-A), hábito de fumar

West Indian Med J 2017; 66 (1): 151

\section{INTRODUCTION}

Smoking is one of the major avoidable causes of cardiovascular diseases worldwide and the risk of acute myocardial infarction (AMI) increases with the number of cigarettes smoked per day $(1,2)$. It is estimated that approximately $30 \%$ of all coronary heart-related deaths are attributed to smoking (3). Smoking claims more lives than do AIDS, drugs, traffic accidents, murder and suicide combined. Currently, the number of smokers worldwide is estimated at 1.4 billion (4), and it is expected that one billion individuals will die as a result of tobacco-related diseases in the $21^{\text {st }}$ Century (5).

Acute coronary syndrome (ACS) is a life-threatening condition that often leads to sudden death and smoking is one of the most important risk factors for ACS (1). However, the molecular mechanism underpinning this relationship is not clear. Pregnancy-associated plasma protein-A (PAPP-A) is a pro-atherosclerotic molecule and it has been established that elevated levels of PAPP-A constitute an independent risk factor for ACS (6). During pregnancy, high concentrations of PAPP-A are produced by trophoblasts and PAPP-A has been used in prenatal screening for genetic anomalies such as Down syndrome (7). Despite its name, PAPP-A is not specific to pregnancy; it is found in both males and non-pregnant females (8). Additionally, elevated PAPP-A levels have also been reported in patients with renal impairment, asthma and lung cancer (9-11). In the present study, we aimed to determine the relationship between smoking and serum PAPP-A levels in men and non-pregnant women.

\section{SUBJECTS AND METHODS}

Study population

The study was conducted at the Acibadem Labmed Clinical Laboratories and Süreyyapasa Chest Disease and Chest Surgery Training and Research Hospital in Istanbul, Turkey. The study population consisted of 112 smokers and 58 age-matched non-smoking healthy controls. The enrolled subjects did not have a history of renal impairment, diabetes, coronary heart diseases, major trauma, or surgery. The demographic characteristics of the study population are presented in the Table. The study protocol was approved by the Ethics Committee of Acibadem University and all subjects provided written informed consent.

\section{Determination of PAPP-A}

Blood samples were drawn from the antecubital vein of all subjects. After clotting, the samples were centrifuged at $1500 \mathrm{~g}$ and sera were stored at $-80{ }^{\circ} \mathrm{C}$ until analysis. All samples of
Table: Subjects' characteristics

\begin{tabular}{|c|c|c|c|c|}
\hline \multirow{2}{*}{ Characteristic } & \multicolumn{2}{|c|}{ Smokers (n: 112) } & \multicolumn{2}{|c|}{ Control (n: 58) } \\
\hline & $\begin{array}{l}\text { Male } \\
\text { (n: 57) }\end{array}$ & $\begin{array}{l}\text { Female } \\
\text { (n: 55) }\end{array}$ & $\begin{array}{l}\text { Male } \\
\text { (n: 27) }\end{array}$ & $\begin{array}{c}\text { Female } \\
(\mathrm{n}: 31)\end{array}$ \\
\hline Age, years & $38.6 \pm 9.8$ & $36.3 \pm 9.1$ & $34.7 \pm 9.0$ & $30.3 \pm 8.4$ \\
\hline BMI & $26.9 \pm 4.6$ & $23.9 \pm 3.9$ & $25.1 \pm 3.2$ & $22.2 \pm 2.4$ \\
\hline $\begin{array}{l}\text { Duration of smoking } \\
\text { (years) }\end{array}$ & $21.3 \pm 9.7$ & $15.9 \pm 8.8$ & NA & NA \\
\hline $\begin{array}{l}\text { Number of cigarettes } \\
\text { smoked per day }\end{array}$ & $20 ;(4-60)$ & $14 ;(2-0)$ & NA & NA \\
\hline Daily alcohol intake & Rarely & Rarely & Rarely & Rarely \\
\hline $\begin{array}{l}\text { Vegetarians or special } \\
\text { diet }\end{array}$ & NA & NA & NA & NA \\
\hline
\end{tabular}

BMI; body mass index

PAPP-A were analysed on the same day in one batch using an ELISA kit (ultrasensitive ELISA kit, DRG Instruments, Marburg, Germany). According to the manufacturer, the withinrun coefficient of variation $(\mathrm{CV})$ was $6.86 \%$ and the detection limit was $0.023 \mathrm{ng} / \mathrm{mL}$.

\section{Statistical analyses}

The Kolmogorov-Smirnov test was used to evaluate the normality of the data. Data are expressed as means \pm SDs or medians and ranges [min-max] (PAPP-A). The Mann-Whitney $\mathrm{U}$ test was used to evaluate the significance of differences between the control and smoking groups. Correlations between variables were assessed using Spearman correlation analysis. Values of $p<0.05$ were considered statistically significant.

\section{RESULTS}

Pregnancy-associated plasma protein-A levels in the study population are shown in Figure 1.

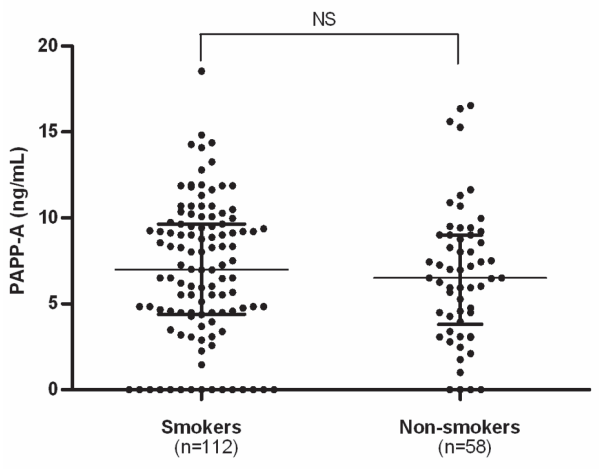

Fig. 1: Pregnancy-associated plasma protein-A (PAPP-A) levels in the study population. 
The difference between the serum PAPP-A levels of all smokers [male and female] $(6.99 \mathrm{ng} / \mathrm{mL}(<0.023 \mathrm{ng} / \mathrm{mL}, 18.6$ $\mathrm{ng} / \mathrm{mL}))$ and non-smokers [control group] $(6.5 \mathrm{ng} / \mathrm{mL}(<0.023$ $\mathrm{ng} / \mathrm{mL}, 16.5 \mathrm{ng} / \mathrm{mL})$ ) was not statistically significant $(\mathrm{p}>$ $0.05)$. However, different results were obtained when serum PAPP-A levels were analysed based on genders. The serum PAPP-A level was significantly high in male smokers [smokers: $9.11 \mathrm{ng} / \mathrm{mL}(3.10 \mathrm{ng} / \mathrm{mL}, 18.55 \mathrm{ng} / \mathrm{mL})$; controls: 7.44 $\mathrm{ng} / \mathrm{mL}[<0.023 \mathrm{ng} / \mathrm{mL}, 16.54 \mathrm{ng} / \mathrm{mL}$ ); $p<0.05)]$ (Fig. 2) but not in female smokers (smokers: $4.49 \mathrm{ng} / \mathrm{mL}(<0.023$ $\mathrm{ng} / \mathrm{mL}, 11.92 \mathrm{ng} / \mathrm{mL})$; controls: $5.95 \mathrm{ng} / \mathrm{mL}[<0.023 \mathrm{ng} /$ $\mathrm{mL}, 15.61 \mathrm{ng} / \mathrm{mL}) ; p>0.05)]$ (Fig. 3).

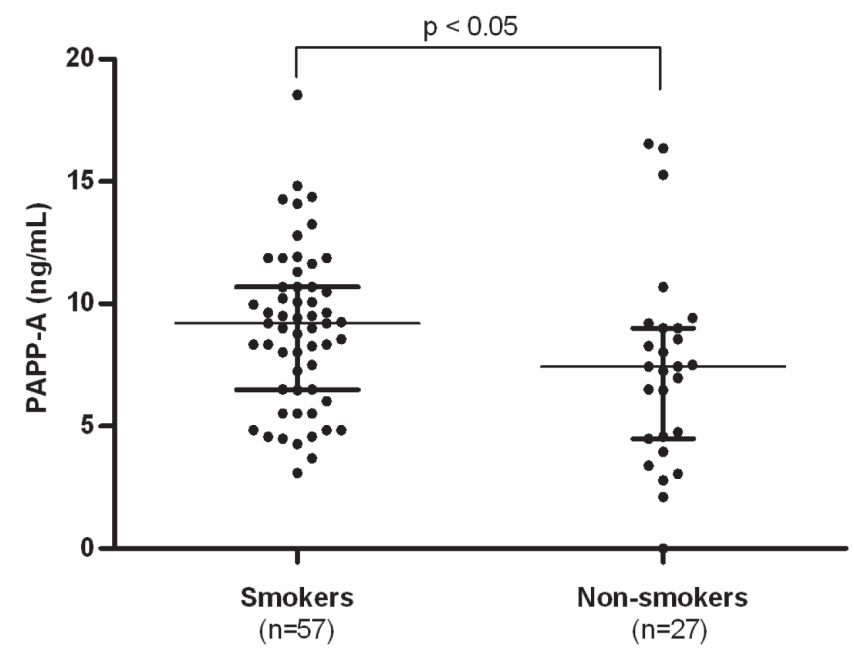

Fig. 2: Serum PAPP-A levels in male population.

In male smokers, the correlation between serum PAPPA levels versus age, body mass index (BMI), duration of smoking (years) and the number of cigarettes smoked per day was not statistically significant $(p>0.05)$.

\section{DISCUSSION}

The present study found that smoking increases serum PAPPA levels in men but not in women. Pregnancy-associated plasma protein-A is a protease (pappalysin-1, EC 3.4.24.79) that has a primary substrate of insulin-like growth factor binding protein-4 (IGFBP-4). The proteolytic activity of PAPP-A is IGF-dependent (ie, it cleaves IGFBP-4 when it is complexed with IGF). The released IGFs are involved in the regulation of the growth, proliferation, and differentiation of various cell types. Several studies have shown that PAPP-A should no longer be considered only "pregnancy-associated". Indeed, expression of PAPP-A has been reported in the kidney, bone, colon, endometrium, testis and other adult and fetal tissues (12-14).

A number of studies have reported that smoking decreases the serum levels of PAPP-A in pregnant women. Al- though researchers demonstrated that smoking decreases birthweight more than five decades ago, no detailed description of the mechanism underlying this phenomenon has been provided (15). The IGF system is crucial to intrauterine growth. During gestation, the main source of PAPP-A is the placenta, and it has been suggested that tobacco alters blood flow to the placenta, causing placental dysfunction by hindering essential nutrient transfer to the fetus. Even low levels of PAPP-A may result in inadequate IGFs, leading to utero-placental insufficiency and disturbances in fetal growth $(16,17)$.

In contrast to the research on pregnant women, detailed studies of PAPP-A levels in non-pregnant smokers have not been conducted. Our literature review revealed only one human study related to cigarette smoking and PAPP-A in men and non-pregnant women. Joaquin et al found no effects of smoking on PAPP-A levels in either men or women (18). In contrast, our study identified a significantly higher level in male smokers than in male non-smokers, but we found no difference in women. Despite its statistical significance, the PAPP-A level of male smokers was not markedly higher than was that of male non-smokers (Fig. 2).

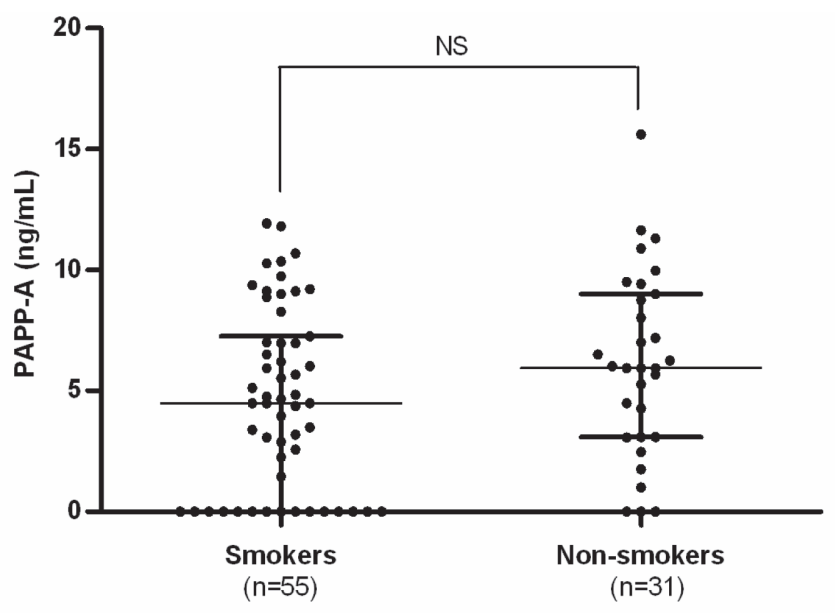

Fig. 3: Serum PAPP-A levels in female population.

Additionally, PAPP-A levels were not significantly correlated with the number of cigarettes smoked per day or the duration of cigarette use (years), but these two values were obtained from a self-administered questionnaire. Thus, the reliability of the self-reported data may be questionable. On the other hand, a threshold level of tobacco metabolites may be sufficient to increase PAPP-A levels in smokers. Smoking is one of the most important causes of acute myocardial infarction (AMI) worldwide; especially in men (2). We suggest that a high level of PAPP-A in male smokers may indicate an increased risk for ACS.

The role of IGFs in the progression of several forms of common human cancers is presently gaining attention (19). In addition to cardiovascular and pulmonary diseases, smoking facilitates the development of tumours such as those of the oropharynx, lung and urinary bladder (20). In our previous 
study, we showed that serum PAPP-A levels were higher in patients with lung cancer than in the control group (11). Recently, it was shown that PAPP-A is synthesized by some types of lung cancer cells (21), and high levels of PAPP-A in male smokers may facilitate the progression of lung cancer by increasing local IGF levels.

The present study had two important limitations. The first is that the data on the duration of cigarette use and the number of cigarettes smoked per day were based on subjects' self-reports and we did not measure our subjects' serum or urine nicotine levels. Secondly, we did not measure free IGF1 and IGFBP-4, which would have helped to interpret the effects of PAPP-A in smokers.

\section{CONCLUSION}

In our previous study, we showed that serum PAPP-A levels were higher in patients with lung cancer than in the control group (11) and it was confirmed that PAPP-A is synthesized by some types of lung cancer cells (21). Serum PAPP-A levels are increased in male smokers, which may indicate a higher risk for ACS in men. However, further studies investigating levels of cotinine, IGF1, and IGFBP-4 are needed to clarify the effect of PAPP-A on smokers and the role of PAPP-A in lung cancer.

\section{REFERENCES}

1. Yagi H, Komukai K, Hashimoto K, Kawai M, Ogawa T, Anzawa R et al. Difference in risk factors between acute coronary syndrome and stable angina pectoris in the Japanese: smoking as a crucial risk factor of acute coronary syndrome. J Cardiol 2010; 55: 345-53.

2. Teo KK, Ounpuu S, Hawken S, Pandey MR, Valentin V, Hunt D et al. INTERHEART Study Investigators. Tobacco use and risk of myocardial infarction in 52 countries in the INTERHEART study: a case-control study. Lancet 2006; 368: 647-58.

3. United States Department of Health and Human Services. Reducing the health consequences of smoking: 25 years of progress. A report of the surgeon general. Public Health $\mathrm{O} \square$ ce, Center for Disease Control, $\mathrm{O} \square$ ce on Smoking and Health. DHHS Publication No (CDC) 1989; 89-8411.

4. http://www.who.int/tobacco/en/atlas38.pdf. Accessed in November 2014.

5. http://www.who.int/tobacco/en/atlas11.pdf. Accessed in November 2014.

6. Bayes-Genis A, Conover CA, Overgaard MT, Bailey KR, Christiansen M, Holmes DR Jr et al. Pregnancy-associated plasma protein A as a marker of acute coronary syndromes. N Engl J Med 2001; 345: 1022-9.
7. Casals E, Aibar C, Martínez JM, Borrell A, Soler A, Ojuel J et al. First trimester biochemical markers for Down's syndrome. Prenatal Diagn 1999; 19: 8-11.

8. Kalousová M, Tesar V, Muravská A, Zima T. Pregnancy-associated plasma protein A: spotlight on kidney diseases. Clin Chem Lab Med 2012; 50: 1183-90.

9. Coskun A, Bicik Z, Duran S, Alcelik A, Soypacaci Z, Yavuz O et al. Pregnancy associated plasma protein $\mathrm{A}$ in dialysis patients. Clin Chem Lab Med 2007; 45: 63-6.

10. Coskun A, Balbay O, Duran S, Annakkaya AN, Bulut I, Yavuz O et al. Pregnancy associated plasma protein A and asthma. Adv Ther 2007; 24: 362-7.

11. Bulut I, Coskun A, Ciftci A, Cetinkaya E, Altiay G, Caglar T et al. Pregnancy-associated Plasma Protein A (PAPP-A) and Lung Cancer. Am J Med Sci 2009; 337: 241-4.

12. Schindler AM, Bischof B. Histochemical localization of pregnancy associated plasma protein-A in fetal, infant, and adult organs and comparison between antisera. Gynecol Obstet Invest 1984; 18: 88-94.

13. Overgaard MT, Oxvig C, Christiansen M, Lawrence JB, Conover CA, Gleich GJ et al. Messenger ribonucleic acid levels of pregnancy-associated plasma protein-A and the proform of eosinophil major basic protein: expression in human reproductive and nonreproductive tissues. Biol Reprod 1999; 61: 1083-9.

14. Conover CA. Key questions and answers about pregnancy-associated plasma protein-A. Trends Endocrin Met 2012; 23: 242-9.

15. Simpson WJ. A preliminary report on cigarette smoking and the incidence of prematurity. Am J Obstet Gynecol 1957; 73: 807-15.

16. Chelchowska M, Maciejewski T, Gajewska J, Ambroszkiewicz J, Laskowska-Klita T, Leibschang J. The pregnancy-associated plasma protein A and insulin-like growth factor system in response to cigarette smoking. J Matern Fetal Neonatal Med 2012; 25: 2377-80.

17. Conover CA, Bale LK, Overgaard MT, Johnstone EW, Laursen UH, Füchtbauer EM et al. Metalloproteinase pregnancy-associated plasma protein A is a critical growth regulatory factor during fetal development. Development 2004; 131: 1187-94.

18. Joaquín C, Granada ML, Pastor C, Castell C, Puig R, Alonso N et al. Pregnancy-associated plasma protein- $\mathrm{A}$ is related to gender and to adipocytokine levels: results of The Health Survey of Catalonia. Clin Endocrinol 2013; 78: 713-23.

19. Boldt HB, Conover CA. Overexpression of Pregnancy-Associated Plasma Protein-A in Ovarian Cancer Cells Promotes Tumor Growth in Vivo. Endocrinol 2011; 152: 1470-8.

20. Deckers JW. Smoking and survival in acute coronary syndrome: the fog is clearing. Eur Heart J 2001; 22: 724-6.

21. Pan H, Hanada S, Zhao J, Mao L, Ma MZ. Protein Secretion Is Required for Pregnancy-Associated Plasma Protein-A to Promote Lung Cancer Growth In Vivo. PLoS One 2012; 7: e48799. 